
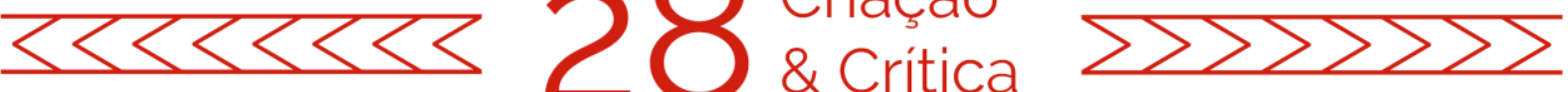

\title{
MULTIÁlogo E ARCO TENSO: POEMAS INTERMÍdIA DE DÉCIO PIGNATARI
}

Monalisa Medrado Bomfim ${ }^{1}$

RESUmo: Décio Pignatari (1927-2012) era o mais irreverente do trio de poetas concretos que compunha junto com os irmãos Haroldo e Augusto de Campos. A ousadia de Pignatari está na sátira, mas também no multiálogo das mídias, que ele experimenta por meio de diferentes suportes nos poemas intermídia. O objetivo do trabalho foi trazer a poesia de Décio Pignatari para o campo de análise do suporte de inscrição, sugerindo um diálogo ativo com o contemporâneo digital. Observa-se que existe algum dado tecnomoderno nos poemas intermídia um movimento (1956), hombre hambre hambra (1957) e caviar (1959), que transitam entre os suportes da página e do áudio. Para compor a discussão teórica do conceito de intermídia foram utilizados os textos: Inter textos/ inter artes/ inter media (2006) e Concrete poetry and the new performance arts: intersemiotic, intermedia, intercultural (2000), de Claus Clüver. Já os textos: A poesia concreta como precursora da cibercultura (2006) e Décio Pignatari entre a vida, os signos e a memória (2016), de Lucia Santaella, articularam o diálogo entre os poemas e o contexto digital.

PALAVRAS-CHAVE: poesia concreta; poemas intermídia; Claus Clüver; Lucia Santaella; suportes de inscrição; intermidialidade.

\section{MULTIALOGUE AND TENSE BOW: INTERMEDIA POEMS BY DÉCIO PIGNATARI}

ABSTRACT: Décio Pignatari (1927-2012) was the most irreverent one in the trio of concrete poets who composed with the brothers Haroldo and Augusto de Campos. Pignatari boldness resides in satire, but also in media's multialogue, which he experiences through the exploration of different supports in intermedia poems. This work aimed to bring Décio Pignatari's poetry to the field of inscription support analysis, suggesting an active dialogue with the digital contemporary. It is observed that there is some technomodern data in the intermedia poems um movimento (1956), hombre hambre hambra (1957) and caviar (1959), which transit between the supports of page and audio. In order to compose the theoretical discussion of the intermedia concept were used the texts Inter textos/inter artes/ inter media (2006) and Concrete poetry and the new performance arts: intersemiotic, intermedia, intercultural (2000), by Claus Clüver. Meanwhile, the texts A poesia concreta como precursora da cibercultura (2006) and Décio Pignatari entre a vida, os signos e a memória (2016), by Lucia Santaella, articulated the dialogue between the poems and the digital context.

KEYWORDS: concrete poetry; intermedia poems; Claus Clüver; Lucia Santaella; inscription supports; intermediality.

Hoje executarei meus versos na flauta de minhas próprias vértebras.

Vladimir Maiakovski A flauta-vértebra

\footnotetext{
${ }^{1}$ Doutoranda e Mestre em Estudos de Literatura, Departamento de Letras, Universidade Federal de São Carlos (UFSCar). E-mail: monabomfim@gmail.com
} 

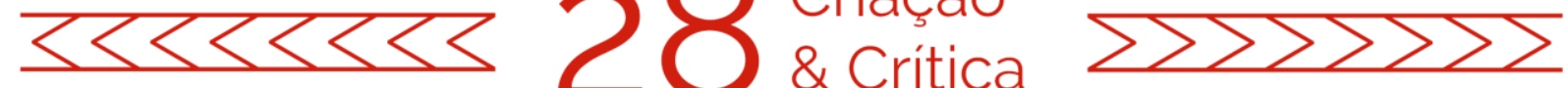

O poema concreto pensa a poesia para além do verso, localiza a palavra não mais na página, mas no espaço-tempo que constitui a malha que suporta a inscrição da palavra, seja esse suporte físico, oral ou, mais recentemente, digital. Dado que a palavra passa a ocupar um espaço-tempo, considera-se também o rearranjo semântico e sintático, no qual o sentido da leitura não se dá apenas da direita para esquerda, mas explora todos os campos espaciais de contato da palavra: palavra-palavra ou palavraespaço. Essa é a sintaxe visual, na qual toda relação importa e pode ser interpretada. A abertura para outras possibilidades organizacionais aproxima o poema concreto do ideograma oriental; os métodos utilizados para isso derivam de uma seleção definida de autores $^{2}$, dos quais destacam-se: Stéphane Mallarmé, James Joyce, Cummings, Erza Pound e Oswald de Andrade. Diferentes textos do livro Teoria da poesia concreta (2006) nos auxiliam a compreender essa proposta de poesia, que explora o espaço-tempo em suas três dimensões: "conteudística", "gráfico espacial" e "acústico-oral" (CAMPOS, 2006, p. 74). A poesia concreta radicaliza as possibilidades da palavra nas três dimensões, é verbivocovisual, para usar um termo joyceano, caro aos poetas concretos.

No contemporâneo, o livro Poesia concreta brasileira (2005), de Gonzalo Aguilar, é referência fundamental para os estudos de poesia concreta. Partindo da reflexão acerca da modernidade e do modernismo no cenário brasileiro, Aguilar (2005) localiza a poesia concreta no espaço-tempo, pensando-a de forma histórica. Diacronicamente, Aguilar (2005) distingue três fases principais da poesia concreta: (1956-1960) fase ortodoxa, (1960-1966) fase participativa e (1967-1969) fase tropicalista. Além disso, debruça-se mais atentamente sobre produções críticas e poéticas dos irmãos Campos, Augusto e Haroldo, citando esporadicamente poemas de outros concretos brasileiros como Décio Pignatari, Pedro Xisto e Ronaldo Azeredo.

O objetivo do presente trabalho é analisar a experimentação dos suportes da produção poética da fase ortodoxa (1956-1960) de Décio Pignatari, conforme divisão de Aguilar (2005). Assim, contemplou-se um poeta concreto ainda pouco explorado nos estudos acadêmicos, com destaque para os poemas: um movimento (1956), hombre hambre hambra (1957) e caviar (1959), produções que experimentam os suportes do papel e do áudio.

Entre as discussões sobre o concretismo que se desdobram no contemporâneo, os trabalhos de Lucia Santaella, precisamente os artigos $A$ poesia concreta como precursora da cibercultura (2006) e Décio Pignatari entre a vida, os signos e a memória (2016), são referências indispensáveis, pois colocam a poesia concreta como precursora da ciberpoesia, ou poesia digital, atual.

\footnotetext{
2 Os poetas concretos brasileiros chamavam essa seleção de paideuma. Nas palavras de Haroldo de Campos (2006, p. 74), paideuma é "elenco de autores culturmorfologicamente atuantes no momento histórico = evolução qualitativa da expressão poética e suas táticas”. Gonzalo Aguilar (2005, p.65), observa ainda que "em grego, 'paideuma' significa ensino, aprendizagem, aquele que se educou. Na terminologia dos poetas concretos, tomada diretamente da proposta poundiana, significa aqueles poetas com os quais se pode aprender".
} 

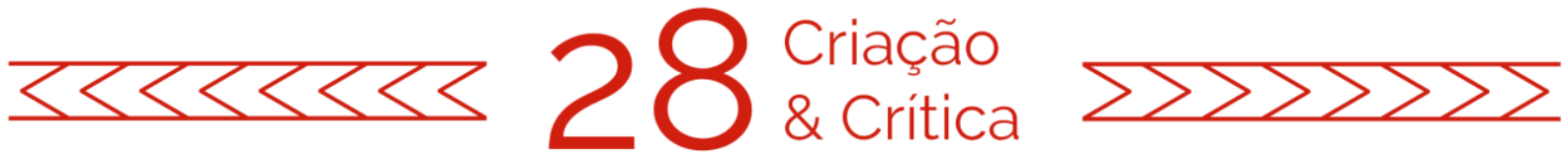

A radicalização a que a poesia concreta levou esses princípios costuma ser chamada de fase ortodoxa da produção dos poetas concretos. Diante dela, a crítica, via de regra, assume um tom condescendente como se a radicalização não passasse de uma fase inicial, depois superada, uma superação que teria levado os poetas concretos a recuarem nos princípios assumidos nessa fase. De outro lado, há também a tendência a se identificar a poesia concreta com as variadas manifestações das poesias visuais. Discordo de ambas as tendências e a história recente da poesia parece estar me dando razão. Por ironia inesperada para os críticos, é justamente o que foi chamado de fase ortodoxa da poesia concreta que a contemporaneidade vem incorporando como herança viva, tanto é que essa herança é tomada como parâmetro daquilo que vem sendo produzido pela e-poesia ou poesia digital contemporânea. (SANTAELLA, 2016, p. 205-206)

Com o texto de Santaella em mente, sugere-se que o dado tecnomoderno do trabalho dos concretos que vem sendo incorporado à modernidade tem a ver com a experimentação dos suportes de inscrição. Isso porque, de acordo com Maingueneau, "a transmissão de um texto não vem após a sua produção, a maneira como ele se institui materialmente é parte integrante de seu sentido" (2001, p. 84). Assim, pensar a experimentação dos suportes importa na medida em que o suporte proporciona inscrição, forma e sentido; principalmente quando se admite como objeto de análise o poema concreto, cuja poesia leva ao extremo as possibilidades da palavra em perspectivas gramaticais, visuais e sonoras. Portanto, a intenção é ilustrar, por meio da análise da produção intermídia de Pignatari, alguns elementos da poesia concreta que podem ser considerados como precursores da literatura digital.

Segundo Santaella $(2016,212)$, Décio Pignatari "adivinhou como ninguém o impacto que as tecnologias pós-revolução industrial e eletrônica viriam acarretar para a cultura e a comunicação". Em entrevista ao programa Roda Viva (1989), na TV Cultura, Pignatari transparece lucidez em relação às tecnologias de seu tempo e destaca que, para além das mídias, o que importa é o multiálogo entre elas:

O bonito não é só a televisão, o que nós estamos vendo de interessante é o diálogo entre as mídias, incluindo a mídia da praça, da coisa a viva voz, pessoal. Então essa coisa viva que é o fato, que gera notícia, esse fato também em si mesmo virou signo, virou linguagem. A praça é pública, mas nem todo mundo pode estar na praça, ela tem que vir através da foto, do cinema e da TV. O que eu acho interessante é o diálogo das mídias, o triágolo, o multiálogo das mídias, uma criticando a outra, e disto é que nasce uma visão um pouco mais completa e interessante. (PIGNATARI, 1989, n.p.)

O diálogo entre as mídias, ou multiálogo como prefere Pignatari, é fato consumado na sociedade digital, na qual a praça pública é amplamente divulgada em tempo real para suportes que estão ao alcance da mão. Santaella observa que, para Pignatari, 

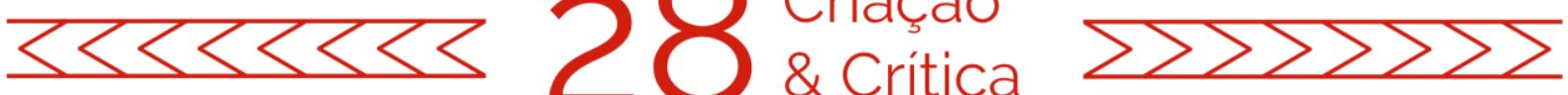

os signos são produzidos nas diferentes mídias, como se comportam, como significam, como são percebidos, interpretados, traduzidos, transformados, transpostos de uma mídia a outra, como são transmidializados faz parte da matéria vivente da comunicação. (PIGNATARI, 2016, p. 212)

Ou seja, os signos sofrem transformações inerentes no multiálogo, pois precisam se adaptar à materialidade de diferentes suportes. Nesse sentido, pensar o multiálogo é pensar também a intermidialidade do objeto artístico e em como o material de inscrição do signo enriquece as possibilidades interpretativas do objeto.

Para pensar o multiálogo das mídias, dá-se um passo atrás para compreender o conceito de intermidialidade, e para isso recorre-se à dois textos de Claus Clüver, Inter textus/ Inter artes/ Inter media (2006) e Concrete poetry and the new performance arts: intersemiotic, intermedia, intercultural (2000). No primeiro texto, Clüver discute os limites dos conceitos associados à palavra intermidialidade, dado que a literatura pressupõe um estudo para além do texto inscrito, mas também, frequentemente, relaciona-se com outras artes e mídias, sobretudo aos suportes no qual se inscreve. Destaca-se no texto de Clüver a relevância de considerar a multimidialidade do novo suporte, isso porque, no processo de trânsito entre suportes, ou mídias, as artes se tocam, se esbarram, trocam estéticas e se entrelaçam quanto à expressividade que apresentam. Com isso em mente, Clüver (2006, p. 20) repensa o conceito de textos intermídia como aqueles que "recorre[m] a dois ou mais sistemas de signos e/ou mídias de uma forma tal que os aspectos visuais e/ou musicais, verbais, cinéticos e performativos dos seus signos se tornam inseparáveis e indissociáveis". Nas palavras do crítico:

Textos intermidiáticos puros que podem existir sem elementos verbais têm, em geral, um caráter performativo, como, por exemplo, certas peças musicais modernas que exigem daqueles que as executam gestos, movimentos e mudanças de lugar dos mais variados modos [...] [que] também são relevantes para as tentativas de interpretação, pois o modo como pensamos sobre as relações dos signos dentro de um texto influencia nossa construção de sentido. (CLÜVER, 2006, p. 31)

Segundo Clüver, o signo é um elemento importante, contudo, não sendo o único, é necessário considerar também outros aspectos no estudo da fronteira entre os suportes, sobretudo a expressão artística que é ressignificada após esse contato. O raciocínio desenvolvido por Clüver coloca o objeto artístico num lugar interdisciplinar, visto que considera as idiossincrasias da materialidade das mídias de inscrição, que, por sua vez, têm afinidades com diferentes disciplinas, como comunicação, literatura, design, música e cinema; mas também o coloca num lugar de multiálogo, pois essas idiossincrasias se tocam, transformando a si mesmas e os signos associados a elas. Clüver observa ainda que o leitor do texto intermídia é outro, ele está em diálogo com a tecnologia, assiste na linha de frente às transformações geradas pelo multiálogo entre mídias e signos, são leitores atentos às possibilidades interpretativas, ativos diante do objeto artístico. 

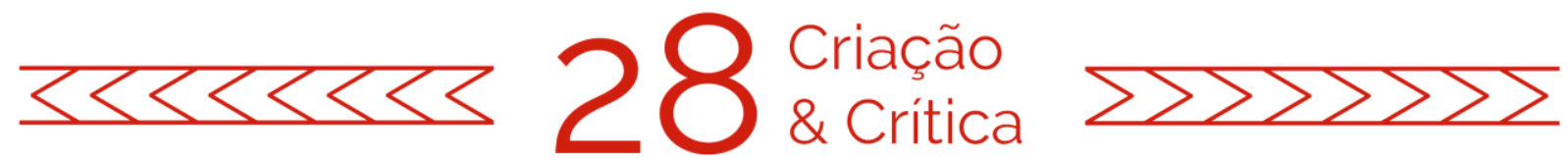

Sobre o objeto intermídia, é importante destacar que as performances orais e corporais podem ser entendidas como suportes que carregam e constroem o sentido do objeto artístico. Em Concrete poetry and the new performance arts: intersemiotic, intermedia, intercultural (2000), o teórico analisa as experiências sonoras empreendidas pela poesia concreta. Para Clüver (2000, p. 38), " [the] concrete sound poetry explore the possibilities of speech sound beyond the limits of speech"3, e a partir disso, depreende-se que os poemas inscritos no suporte do áudio, por meio da performance oral, exploram as possibilidades do falar, isto é, dos fonemas da linguagem e da melopeia poética.

O texto considera ainda que as interferências instrumentais e harmônicas promovem outra experimentação do suporte do áudio, pois oferecem ao leitor uma experiência que explora a performance oral em diálogo com a música. Nesse ponto, Clüver distingue a poesia concreta, pois observa nela uma afinidade com a proposta intermídia.

Concrete poetry lends itself well to demonstrating the possibilities inherent in intersemiotic and intermedia texts even of minimal proportions, to exploring the potential of such texts to appeal to audiences across linguistic and cultural boundaries even when different writing systems are involved, to indicating new demands made on readers as texts leave the page to become three-dimensional objects that require physical manipulation, and to exemplifying new concepts of performance with regard to the text executing itself as a programmed structure, the oralization of "open" verbivocovisual texts, and the role of the reader as game player, operator, and quasi-coauthor. ${ }^{4}$ (CLÜVER, 2000, p. 47)

A poesia concreta revolucionou o cenário poético ao se apresentar em três dimensões que exploram a verbivocovisualidade da palavra. A proposta intermídia oferece aos poemas concretos meios e suportes outros, pois disponibiliza recursos para além da folha de papel e da inscrição na página, ampliando a experimentação das três dimensões poéticas. A intermidialidade aparece na produção de Décio Pignatari carregada de um dado tecnomoderno; encontra-se aí o sabor de poesia concreta que se degusta no contemporâneo, no sentido metafórico do termo, isto é, assim como um resquício concreto ortodoxo sobrevive em parte da literatura digital, é possível senti-lo quando se saboreia os poemas.

Aguilar subdivide a fase ortodoxa em outras duas: fase orgânica e fase matemática, de acordo com ele:

\footnotetext{
${ }^{3}$ Tradução própria: "a poesia concreta sonora explora as possibilidades do som falado para além dos limites da fala".

${ }^{4}$ Tradução própria: "a poesia concreta demonstra por si mesma as possibilidades inerentes aos textos intersemióticos e intermídia, mesmo que de proporções mínimas, de explorar o potencial desses textos de atrair o público através de aproximações linguísticas e culturais, mesmo quando diferentes sistemas de escrita estão envolvidos, indicando novas demandas construídas por leitores de textos que deixam a página para se tornarem objetos tridimensionais, que requerem uma manipulação física, e que exemplificam novos conceitos de performance que dizem respeito à execução do texto em si como uma estrutura programada, a oralização dos textos verbivocovisuais "abertos" e o papel do leitor como jogador, operador e quase co-autor".
} 

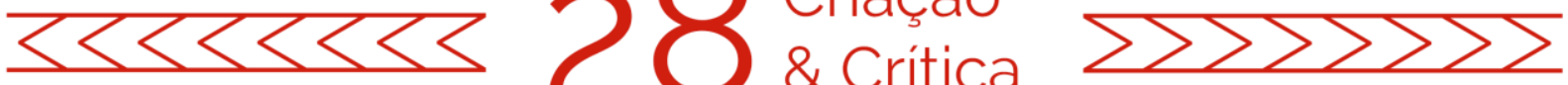

A experimentação com essas relações espaciais permite, na produção do período 1955-1960, estabelecer as diferenças entre o que se denominou "fase orgânica" e "fase matemática". No primeiro caso, predomina um tipo de relacionamento entre as partes bastante similar ao de Un coup de dés, um ordenamento irregular que trabalha com a página a partir de agrupamentos relativos às exigências contingentes de cada poema. (AGUILAR, 2005, p. 194)

Partindo do conhecimento de que Mallarmé é um importante precursor da poesia concreta, lembra-se que esse movimento poético se empenhou em levar até as últimas consequências o projeto mallarmeano de Un coup de dés $(1897)^{5}$, rompendo com estruturas discursivas e submetendo a palavra à experimentações de linguagem, de forma e estéticas. Desse modo, o espaço em branco ganha importância simbólica no poema, que pode ser lido como uma partitura músical.

Em seu texto, Aguilar (2005, p. 243) observa ainda que "a crítica mais contundente do verso está nos poemas da 'fase orgânica', [...] nos quais o verso empresta as forças que lhe restam como forma”. O poema um movimento (1956) é um exemplo de produção da fase orgânica.

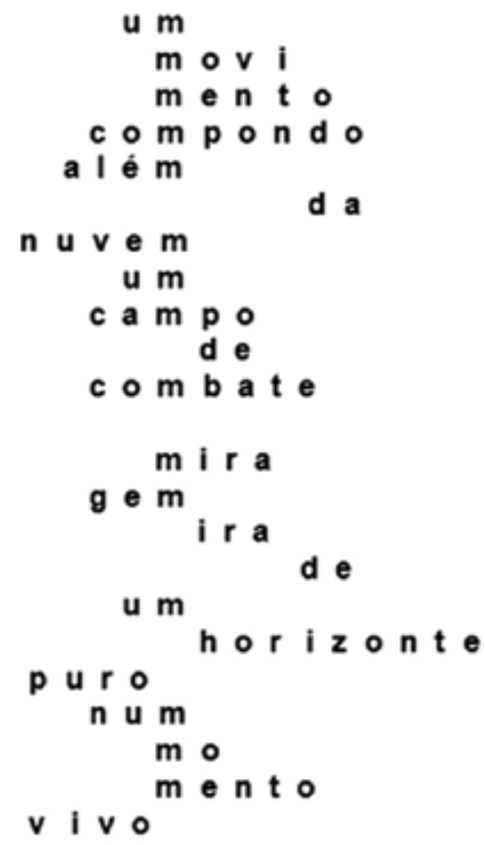

Figura 1. Poema um movimento (1956), de Décio Pignatari. ${ }^{6}$

O poema de Pignatari não possui estrofes, tampouco versos, ele é um único bloco, no qual o branco também participa da tecedura da malha do texto de maneira

\footnotetext{
${ }^{5}$ Haroldo de Campos o define como um "poema de pouco mais de 10 páginas [que] pode ser considerado, justamente, uma espécie de épica dos novos tempos, uma épica sintética e condensada do espirito crítico em luta com o Acaso e meditando sobre a possibilidade mesma da poesia, cuja morte ou cuja crise havia sido vaticinada por Hegel" (1979, p. 285).

${ }^{6}$ Teoria da poesia concreta, 2006, p. 131.
} 

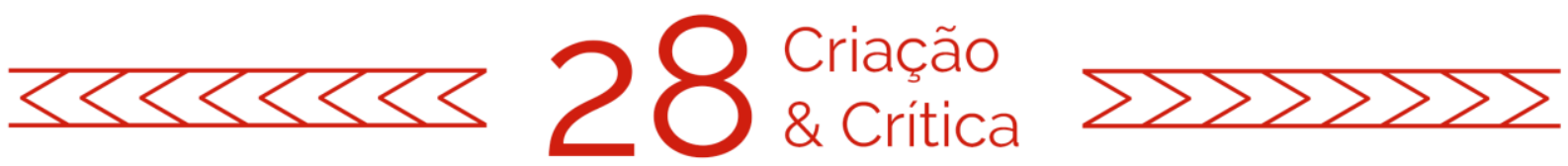

mallarmeana, assim, palavras e brancos compõem o espaço-tempo. Nesse ponto, não apenas a palavra é experimentada em seus limites, mas o branco também: ele ocupa espaço, variando de tamanho e local, de modo que as palavras parecem ganhar movimento em algo orgânico e incolor, como por exemplo, o vento ou a água. Aqui, esse algo é associado ao vento, sobretudo devido a aliteração da letra $<\mathrm{v}>$ nas palavras "movimento", "nuvem" e "vivo", que somadas à repetição das vibrantes [r] e fricativas [z], estimula na mente do leitor o ruído provocado por correntes de vento.

A despeito do movimento orgânico das palavras, há no texto um eixo de apoio constituído pela letra $<m>$, que mantém as palavras unidas por meio de um fator comum. Quase em divagação, propõe-se que, talvez para Pignatari, o vento que carrega as palavras em movimento orgânico seja na verdade a geleia geral brasileira, enquanto as sólidas vertebras que protegem a medula são as letras $<m>$, isto é, o arco tenso, a persistência da poesia concreta na literatura nacional. Essa hipótese recorre ao trecho final do texto \& se não perceberam (1966), publicado pela primeira vez na revista Invenção no 5 e incluído no livro Teoria da poesia concreta:

[...] certa vez um biacadêmico poeta de 'vanguarda' nos disse: o arco não pode permanecer tenso o tempo todo, um dia tem de afrouxar \& um dia vocês têm de afrouxar \& nós: na geléia geral brasileira alguém tem de exercer as funções de medula e osso. (PIGNATARI, 2006, p. 235)

Pignatari escreve em resposta à crítica de Cassiano Ricardo, que falava para os poetas concretos afrouxarem o arco. Pignatari é categórico, o arco permaneceria tenso, fazendo papel de coluna vertebral (medula e osso) no cenário literário brasileiro, que ele considerava geleia, ou seja, pastosa e instável. No poema um movimento, conforme imagem acima, além de observar a instabilidade dada pela disposição das palavras, colocadas entre os espaços brancos, sugere-se ainda que os trechos que dizem sobre 0 "campo de combate" e "miragem ira" falem sobre a resistência e a crítica que a poesia concreta enfrenta no campo intelectual e literário brasileiro. Aguilar observa, por exemplo, que as opiniões sobre a poesia concreta são "frequentemente impregnadas de certa violência e distribuídas dicotomicamente: ou se está a favor ou contra" (2005, p. 15). Com isso em mente, retorna-se ao poema para observar o campo de batalhas ligado a essa dicotomia, a "ira", já antecipada como eco na palavra "mIRAgem", é o ódio que se perpetua nesse local de contínuo combate. As palavras cheias de violência do poema vão e vêm em movimento suave, que expõe a contradição do contexto da crítica literária.

Assumindo a coluna de letras $<m>$ como eixo, observa-se ainda a mobilidade na fonética das letras, como por exemplo no fragmento entre "um" e "horizonte", em que há uma forma fixa: do lado direito do poema concentra-se a letra plosiva palatal $<c>$, do lado esquerdo as plosivas bilabiais $\langle p\rangle$ e $\langle b\rangle$, assim, o som também fica em movimento dentro da boca, passando do palato aos lábios, linha a linha, isto é, as palavras são postas para fora, como desabafo. Após a palavra "horizonte", a repetição muda, a letra $<\mathrm{p}>$ do lado direito e a letra $<\mathrm{t}>$, plosiva alveolar, do lado esquerdo do eixo, ou seja, 0 movimento na boca inverte-se dos lábios ao céu da boca: é o retorno da palavra para 

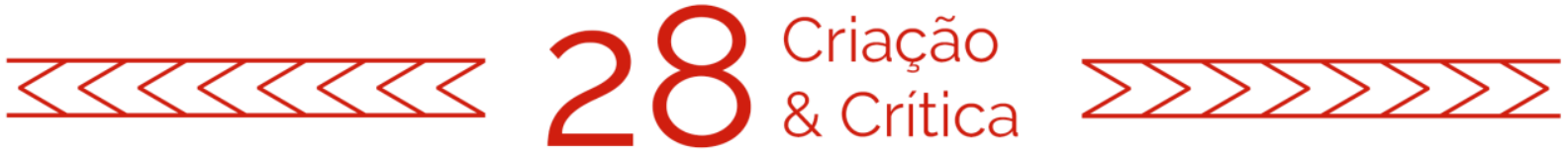

dentro daquilo que é "vivo". Essa alternância de movimentos ajuda a caracterizar a qualidade orgânica dele, que pulsa, como coisa viva, para frente e para trás.

No texto escrito, a fragmentação das palavras já carrega um dado tecnomoderno; no entanto, esse dado tem mais a ver com a fragmentação moderna proposta por Oswald de Andrade em Memórias sentimentais de João Miramar (1924), do que com a cibercultura. Não por acaso, em um movimento (1956), lê-se as palavras "mira" e "miragem" no enjambement central, ambas rememoram o nome do protagonista de Oswald. Por outro lado, quando o poema experimenta o suporte do áudio, o elemento de fragmentação dele toca o contexto digital, é o que se percebe na performance oral do grupo de coral Madrigal Ars Viva, regido por Klaus-Dieter Wolff (1971) ${ }^{7}$. A performance é composta em ré menor e alonga o enunciado das letras $\langle\mathrm{m}\rangle,\langle\mathrm{v}\rangle$ e $<\mathrm{r}\rangle$, consoantes do verbo mover.

O áudio de um movimento (1971) começa com um ruído branco, o prolongamento da palavra "um", que pode indicar o início do processo de meditação ou a imersão no poema. Esse início dá outra densidade espectral ao objeto artístico, sente-se, já no princípio, a potência da experimentação do suporte do áudio. Na sequência, o som nasal [m] liga as palavras "movimento" e "compondo": novamente, a letra <m> aparece como a coluna vertebral ereta do poema e as palavras atingem o ouvinte como ventania. No áudio, a sonoridade do vento também se dá na pronúncia prolongada da letra <i>, em "movlmento". O trecho "além da" repete-se, como eco, chamando a poesia concreta para a discussão, pois é uma poética que vai além da página, ou além da geleia geral. Em certo momento, a repetição é interrompida por um estampido, a plosão de [d], cuja vocalização ganha força com a abertura promovida pela vogal [a]. O silêncio, posterior à explosão, retoma o espaço em branco entre "além" e "nuvem" do poema escrito.

Subindo a cima das nuvens e ainda mais alto, a pronúncia da palavra "nuvem" eleva o tom da composição, nela o som [m] é recolocado na posição de medula e osso. Retomando a interpretação proposta para o poema escrito, em um movimento (1971), a poesia concreta também é arco tenso, bate de frente com a crítica que a acortina com silêncio, talvez aí esteja a origem do grito agudo que permeia a oralização do "campo de combate" e da "miragem ira", cujas plosões de [p], [b] e [d] sonorizam a troca de tiros numa batalha. Árdua e ácida, a batalha é violenta aos ouvidos, mas o horizonte adiante é calmo e tranquilo. Nesse ponto, é interessante reparar como no poema escrito "horizonte" e "puro" estão separados por um grande espaço em branco, e assim não há o impulso de lê-lo como enjambement; o áudio, por outro lado, os aproxima, enunciando "horizonte puro". Nesse caso, "puro" não é usado no sentido de algo sublime ou inocente, mas como algo que transmite paz, o horizonte de esperança, que se contrapõe ao "campo de combate" ou, ao menos, dá um futuro possível a ele.

É curioso notar que, na versão regida por Klaus-Dieter Wolff (1971), a última linha de um movimento (1956), a palavra "vivo" não é pronunciada, talvez porque ela já esteja implícita nas vidas das vozes que entoam o poema. Porém, o mesmo não acontece na

${ }^{7}$ Disponível em: <https://poesiaconcreta.com.br/player.php?acao=play\&id=285\&numero=1>. Acesso em: 20 mai. 2020. 

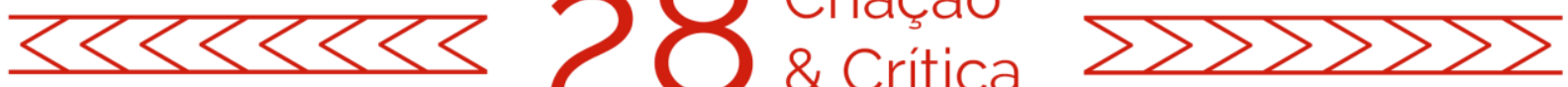

performance oral do próprio Pignatari $(2002)^{8}$, na qual o poema é declamado inteiro de forma objetiva, com as palavras bem marcadas na pronúncia, promovendo uma experiência auditiva do poema diferente da proposta em 1971. A declamação de Pignatari reparte o poema em três estrofes e coloca pelo menos duas pausas rápidas e significativas.

Em um movimento (2002), a primeira parte vai de "um" a "nuvem", ela é falada lentamente e, mais uma vez, a aliteração da letra $<\mathrm{v}>$ nos remete ao vento, enquanto a nasalização de [m] coloca o eixo em que as demais sílabas se apoiam. No que seria o espaço entre "além" e "da" no poema escrito, Pignatari silencia, faz uma pausa rápida, mas notável. A segunda parte, "um campo de combate", é pronunciada de supetão, sem respiro. Na terceira parte, que se inicia com "mira", o tom do poeta se eleva gradativamente até a palavra "ira", cujo som [e] favorece a vocalização da voz elevada: se há estampido nessa versão do poema, ela está nessa letra <a>. O espaço em branco entre "horizonte" e "puro" no poema escrito é oralizado como pausa rápida, desse modo, apesar da voz de Pignatari soar calma, a palavra "puro" não remete mais à tranquilidade, mas a algo livre de impurezas, algo de essência purificada. A pureza está "num momento vivo", que é a praça pública da fala de Pignatari, mas também é o momento presente. Assim, diferente do horizonte de esperança da oralização de 1971, a performance oral de 2002 mira o horizonte do presente.

Uma pequena pausa é capaz de mudar a leitura do objeto artístico. Operando pelas beiradas a experiência intermídia expande os significados, modela o espaço-tempo e repensa as interpretações, ainda que tudo parta da palavra, as diferentes maneiras de pronunciá-las, os diferentes enjambements que podem ser conectados ou ignorados. Os diferentes caminhos de leitura ganham uma dimensão outra quando pensados da perfectiva do suporte digital. Conectar ou não um enjambement significa escolher ativamente uma estratégia de leitura, se substituirmos o enjambement por links URL, temos o que no contexto digital é chamado de hipertexto, no qual o leitor realiza uma leitura não linear, opinando ativamente no rumo do texto. Nesse sentido, a fragmentação dos objetos intermídia de um movimento (1956, 1971 e 2002) pode ser considerada como a fase embrionária da fragmentação dos hipertextos digitais, pois os múltiplos caminhos de leitura, que multiplicam as interpretações possíveis, estão diretamente ligados à materialidade do objeto artístico.

O segundo momento da fase ortodoxa da poesia concreta é a fase matemática, de acordo com Pignatari é o "estágio mais avançado de evolução formal", "mais racional de criação", no qual "predomina a forma geométrica ou matemática" (2006, p. 129). Dentre as formas geométricas, Aguilar destaca a quadrícula:

Ao dispor os signos no espaço de modo regular, as formas geométricas quadriculares (sintéticas e simultâneas) pretendem substituir as disposições lineares do verso (sucessivas e recursivas). Desse modo, o poema concreto se distancia ainda mais das formas narrativas da

${ }^{8}$ Disponível em: <https://poesiaconcreta.com.br/player.php?acao=play\&id=175\&numero=29>. Acesso em: 20 mai. 2020. 

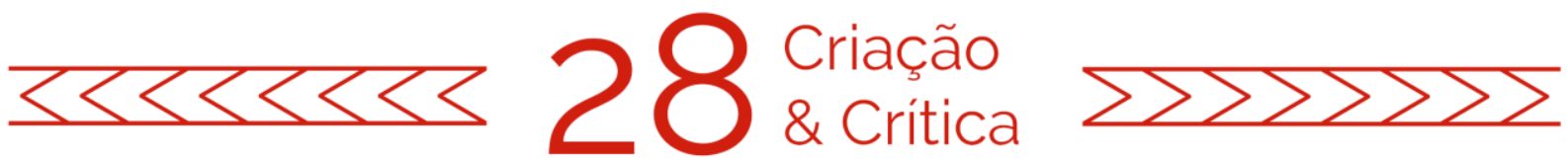

discursividade poética e se aproxima do trabalho espacial da pintura e da música que lhe são contemporâneas. (AGUILAR, 2005, p. 203)

Aguilar firma a desconstrução completa do verso na fase matemática, definitivamente não há mais versos, mas poemas visuais, pensados de maneira ideogrâmica, e não apenas como pura estética ótica. Com isso em mente, os próximos poemas foram lidos como ideogramas ou hieróglifos, nos quais a combinação dos signos sugere um significado oculto, para além do significado das palavras utilizadas. Esse argumento se sustenta a partir do texto de Santaella, para a qual:

[...] os poetas concretos souberam extrojetar na superfície da página o cerne diagramático da linguagem poética: tornar visível seus diagramas internos multiplamente direcionados, formas que desenham sentidos. $O$ resultado desse processo, embora visível, traz à baila processos que estão mais próximos do visual ideogrâmico do que do visual ótico. É dentro desse contexto que a visualidade da poesia concreta deve ser pensada, o que implica necessariamente a conjunção do olho e do ouvido na correlação com as formas da música, invisíveis aos olhos. Não é por acaso que o lema dos concretos estava no ideal verbivocovisual. Também não deve ser por acaso que a paternidade dos poetas concretos é reconhecida pela e-poesia atual [...]. (SANTAELLA, 2006, p. 35)

De acordo com Santaella, a verbivocovisualidade da poesia concreta deve ser explorada ideogramicamente, bem como a visualidade da poesia digital, posto que uma é precursora da outra. A poesia concreta carrega, portanto, aspectos dessa cultura outra que ainda estaria por vir, a cultura dos suportes digitais. Antes da revolução digital, o sabor do multiálogo das mídias é experimentado por meio dos diferentes suportes, como no caso dos poemas intermídia de Pignatari.

Retornando ao texto de Aguilar e à predominância da forma da quadrícula, sinaliza-se que os próximos poemas aderem à essa forma, por isso, permitem uma leitura multilateral, isto é: na horizontal, vertical, diagonal, da direita para esquerda e vice-versa, de cima para baixo e vice-versa. O primeiro poema da fase matemática analisado é hombre hambre hembra (1957):

$\begin{array}{lll}\begin{array}{l}\text { hombre } \\ \text { hambre }\end{array} & \text { hombre } & \begin{array}{l}\text { hombre } \\ \text { hembra }\end{array} \\ \text { hembra } & \begin{array}{l}\text { hambre } \\ \text { hembra }\end{array} & \text { hambre }\end{array}$

Figura 2. Poema hombre hambre hambra (1957), de Décio Pignatari. ${ }^{9}$

\footnotetext{
${ }^{9}$ Teoria da poesia concreta, 2006, p. 174.
} 

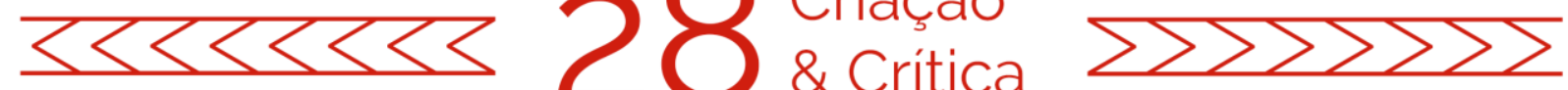

Publicado pela primeira vez na revista Noigandres $\mathrm{n}^{\circ} 4$, o poema hombre hambre hembra (1957) utiliza palavras do espanhol e o espaço em branco como elementos do texto. Rapidamente, tendo como referência a primeira coluna do texto, de cima para baixo, tem-se a tradução das palavras: homem, fome e fêmea. Obviamente, a escolha do espanhol, propriamente do castelhano, permite o jogo de troca das vogais $<a>$, $<e>e$ $<0>$, enquanto a matriz de consoantes da palavra permanece a mesma $\left(<\mathrm{h} \_m b r \_>\right)$, de acordo com Aguilar (2005, p. 207), este é "o único idioma em que esse jogo de palavra é possível"10. No poema, a imagem do jogo de palavras é literal e antimimética, homem e mulher são constituídos da mesma essência, a fome, que também pode ser entendida como o desejo que reside no âmago do ser. Entre homens e mulheres, a fome é a constante, fome do alimento que mantém a vida, fome de sexo que reproduz a vida.

Ampliando o diálogo interdisciplinar que a poética concreta preconiza, agrega-se conhecimentos biológicos à leitura, pois as vogais se alternam nas palavras do poema como as bases nitrogenadas se alternam no $\mathrm{DNA}^{11}$ da célula. Com isso em mente, entende-se o poema como informação genética poética, que explica a dinâmica da vida no nosso planeta, isso inclui o homo sapiens, mas também grande parte dos animais e plantas. É interessante notar ainda que na primeira linha existe uma predominância da palavra "hombre", do latim homo, que nos identifica como espécie homo sapiens, mas também projeta a dicotomia machos e fêmeas. Nesse sentido, o poema une à dinâmica da vida o domínio do humano sobre as demais espécies e do homem sobre a mulher.

No centro do poema há um espaço em branco seguido da palavra "hambre", o que reforça a sugestão de que a fome reside no âmago daquele que vive. Se o poema for lido em colunas, a palavra "hambre" aparecerá sempre próxima de um espaço em branco, o que é simbólico na medida em que se fala sobre o sentimento da fome, que é costurado ao sentimento de falta: o vazio do estômago, a solidão que antecede a chegada do amante e o vazio que fica quando a coisa amada parte. O mais interessante é explorar o texto em todas as suas possibilidades de leitura, jogando com os caminhos e os fonemas. A diversidade de caminhos do texto escrito se dilui nas performances orais que Kátia Guedes e José Augusto Mannis ([1998] 2007) ${ }^{12}$ e Décio Pignatari (2002) ${ }^{13}$ produzem do

\footnotetext{
${ }^{10}$ Gonzalo Aguilar (2005, p. 207) observa ainda as características tipográficas de hombre hambre hembra (1957), escreve que "esse poema extrai seu sentido da lei de proximidade e da confusão entre o 'a' e o 'o', o que só é possível pela tipografia utilizada (a futura bold, como em todos os poemas da fase ortodoxa)".

${ }_{11} \mathrm{De}$ acordo com a definição do bioquímico Bruce Alberts, "uma molécula de ácido desoxirribonucleico (DNA) consiste em duas longas cadeias polipeptídicas compostas por quatro tipos de subunidades nucleotídicas. Cada uma dessas cadeias é conhecida como uma cadeia de DNA, ou fita de DNA. As cadeias são antiparalelas entre si, e ligações de hidrogênio entre a porção base dos nucleotídeos unem as duas cadeias. [...] os nucleotídeos são compostos de açúcares com cinco carbonos, aos quais um ou mais grupos fosfato estão ligados, e uma base contendo nitrogênio. No caso dos nucleotídeos do DNA, o açúcar é uma desoxirribose ligada a um único grupo fosfato (por isso o nome ácido desoxirribonucleico), e a base pode ser adenina (A), citosina (C), guanina (G) ou timina (T)." (et al. 2017, p. 175).

${ }^{12}$ A primeira performance oral do poema hombre hambre hambra (1957), foi realizada em 1998, contudo, o áudio disponível para consulta data de 2007. Disponível em: <https://poesiaconcreta.com.br/player.php?acao=play\&id=292\&numero=8>. Acesso em: 20 mai. 2020.

${ }_{13}$ Disponível em <https://poesiaconcreta.com.br/player.php?acao=play\&id=178\&numero=32>. Acesso em 20 mai. 2020.
} 

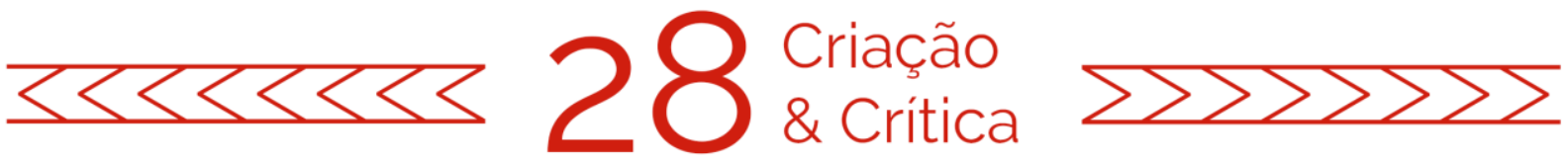

poema, pois realizam a leitura predominantemente na vertical. A declamação do poema, em ambos os casos, respeita a disposição dos espaços em branco conforme posto no escrito, traduzindo-o por silêncio ou pausa longa.

A performance vocal de Kátia Guedes é musicada por José Augusto Mannis (2007), unindo voz e música erudita. Na oralização, o poema é recitado uma única vez, obedecendo às colunas da direita para esquerda, de cima para baixo. Mannis compõe musicalmente a performance com sons de soprano, clarinete e piano. Nas palavras do compositor:

Dès le moment où je suis tombé sur les mots HOMBRE (homme), HEMBRA (femelle) et HAMBRE (faim) disposés en trigrammes, mon imagination a été réveillée et partie en vols variés. Le poème, le matériel et son support étaient si étroitement liés les uns aux autres au point de ne plus être possible de les séparer. Le travail devait donc se poursuivre directement sur la substance du poème. Pour une 'trancréation' effective il était important d'éviter le simple accompagnement sonore du poème lu et partir à la recherche d'un son poétique issu du corps du poème concret. Les jeux identifiés au poème Hombre ont été transportés à la construction musicale : variations entre les formants de voyelles <a / e / o> transformés en sons filtrage; la consonne bilabial $<m>$ est devenue un mode de jeu vocal : chanter avec la boca chiusa; le roulement des $<r>$ devient frullato (flatterzunge) et aussi des sons différentiels entre soprano (hembra) et clarinette (hombre) produits par la superposition des notes proches, surtout en intervalles inférieurs à une tierce, dont le résultat de l'interférence acoustique produit un troisième son (hambre), presque un bourdonnement provoqué par des battements entre les ondes sonores. Noigandres IV s'est établie finalement comme une pièce d'intense émotion. ${ }^{14}$ (MANNIS apud EL HAOULI e MANNIS, 2014, p. 137)

A performance sonora de Guedes e Mannis é dividida em dois momentos: primeiro aquele no qual dominam a voz e o piano, com a declamação do poema, o segundo com a inclusão dos demais instrumentos, como esclarece Mannis (2014), que explica o diálogo entre os sons do clarinete (hombre) e soprano (hembra) gerando um terceiro som (hambre). Na segunda parte, as consoantes $<\mathrm{m}>\mathrm{e}<\mathrm{r}>$ mantidas entoadas

\footnotetext{
14 Tradução própria: "desde o momento que me deparei com as palavras HOMBRE (homem), HEMBRA (fêmea) e HAMBRE (fome) dispostos em trigramas, minha imaginação despertou e ascendeu vários voos. $O$ poema, o material e seu suporte estavam tão intimamente ligados entre si, a ponto de não ser mais possível separá-los. O trabalho, portanto, teve que perseguir diretamente a substância do poema. Para uma 'transcriação' efetiva era importante evitar o simples acompanhamento sonoro do poema lido e procurar um som poético que fosse corpo do poema concreto. Os jogos identificados no poema Hombre foram transportados para a construção musical: variações entre as vogais formantes <a / e / o > transformados em sons filtrantes; a consoante bilabial $<\mathrm{m}>$ passou a ser um modo de jogar com o vocal: cantar com a boca fechada. $O$ frêmito do <r> torna-se móvel (flatterzunge) e também a combinação de tons do soprano (hembra) e clarinete (hombre) produzidos pela sobreposição das notas fechadas, especialmente em intervalos inferiores a um terço, cujo resultado da interferência acústica produz um terceiro som (hambre), quase um zumbido causado por batidas entre as ondas sonoras. Noigandres IV finalmente se estabeleceu como um pedaço de intensa emoção".
} 

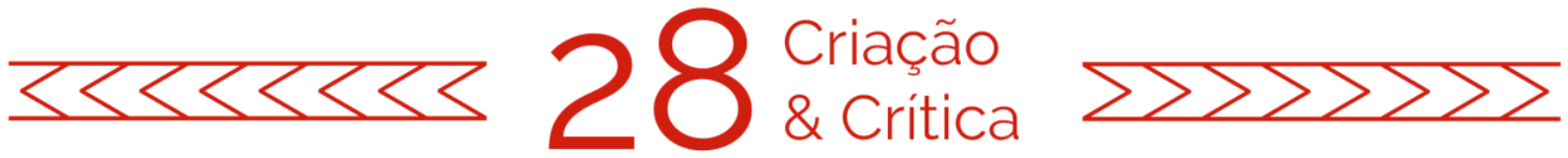

como ópera, remetem e estendem a presença da matriz $<\mathrm{h}$ mbr_ $>$, que aparece como uma constante, enquanto os instrumentos se alternam, bem como as vogais se revezam no poema escrito. Ainda na segunda parte, a articulação dos sons [m] e [a] elevam tom de agudo da performance, despertando o sentido auditivo para um ruído semelhante ao vento, que produz um efeito de movimento e, até mesmo, um certo suspense.

A análise que Veruschka Bluhm Mainhard realiza da partitura de hombre hambre hembra (1998) sinaliza que "o compositor representa a fome por sons que não estão efetivamente escritos na partitura", ela "é traduzida pelos harmônicos resultantes, que possuem uma qualidade de rarefação no timbre" (2013, p. 6-7). Retomando a análise do poema escrito, na qual a palavra "hambre" é observada sempre próxima a um espaço em branco, sugere-se que a performance sonora de Mannis (2007) traduz esse aspecto quando materializa a fome naquilo que falta, aquilo que não está na partitura, atando fome e ausência em uma coisa só.

A performance oral de Décio Pignatari (2002), por sua vez, toma outro caminho, explora o espaço do poema escrito por meio do silêncio, não combinando nenhum outro fator harmônico. Aqui, são as possibilidades de leitura que são exploradas: o poema é lido três vezes, sempre obedecendo às colunas, duas vezes da direita para esquerda, de cima para baixo, interpolada de uma leitura da esquerda para direita e de baixo para cima, esta última, pouco intuitiva para leitores ocidentais. A oralização de Pignatari fornece um vislumbre do oriente, de uma cultura linguística outra, ideogrâmica. A fome aparece, mais uma vez, como parte do homo sapiens como espécie, independente da cultura.

Após observar um aumento do universo sinestésico e simbólico do poema hombre hambre hembra (1957) em diferentes suportes (2002 e 2007), tem-se que a experimentação intermídia possibilita que o leitor construa alguma totalidade com os fragmentos. A construção do universo do poema depende, novamente, da atividade do leitor, responsável por pensar o multiálogo das mídias, ou seja, retornar ao escrito e aos outros suportes, repensando as interpretações e sensações. Os fragmentos se espalham em diferentes inscrições, nessa medida, a totalidade é abstrata, pois o objeto artístico está aberto a ser repensado em outro suporte, principalmente quando consideramos 0 viés do contexto digital, pois nele as possibilidades de experimentações aumentam. A totalidade também é abstrata no sentido que Roger Chartier propõe para o suporte digital, pois para ele:

A descontinuidade existe até mesmo nas aparentes continuidades. Ante o monitor, a leitura é uma leitura descontínua, segmentada, mais ligada ao fragmento do que à totalidade. [...] A descontinuidade e a fragmentação da leitura não têm o mesmo sentido quando acompanhadas pela percepção da totalidade textual encerrada no objeto escrito e quando a superfície luminosa que apresenta à leitura os fragmentos de escritos já não torna imediatamente visíveis os limites e a coerência do corpus ao qual pertencem como extratos. (CHARTIER, 2010, p. 9) 

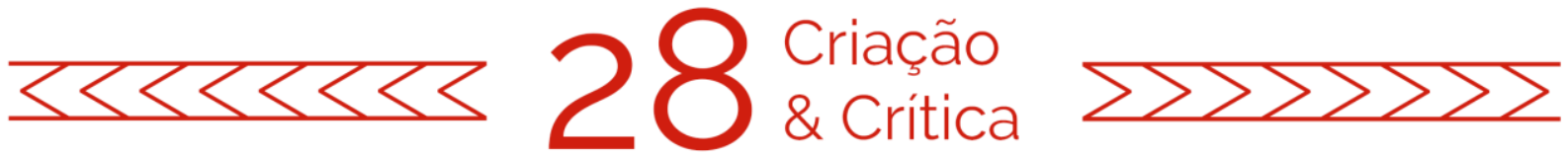

Pensando em termos de suporte, o livro e o monitor, por exemplo, oferecem totalidades diferentes do objeto artístico. O monitor concentra mídias, pode reproduzir tanto o livro como o filme, o suporte da tela é o mesmo, não há variação física para o leitor; por outro lado, nos livros, cujos volumes e edições variam, há uma compreensão distinta da totalidade da obra. Além disso, os suportes digitais, como o monitor, oferecem uma concepção descontinua e fragmentada do objeto artístico, pois a tela o segmenta, alguma continuidade aparente se dá apenas nos jogos mentais do leitor. A totalidade abstrata observada no objeto intermídia hombre hambre hembra (1957, 2002 e 2007) se aproxima da fragmentação observada por Chartier ao passo que cada experimentação recorta uma totalidade da obra, oferecendo fragmentos que dependem de uma ação ativa de busca e interpretação. No entanto, a reunião das experiências resulta apenas em uma continuidade aparente, pois antes de se fechar, ela abre o poema para outras possibilidades interpretativas. Portanto, o poema de Pignatari parece já exigir um leitor ativo parecido com o do contexto digital - existe aí um aspecto que ambas as produções compartilham.

Caviar (1959) é mais um poema em quadrícula de Pignatari que mantém o arco da poesia concreta tenso. Composto em quatro linhas de quinze caracteres cada, incluindo os espaços, também possibilita diversas leituras, linha a linha, de cima para baixo e vice-versa; ou como duas colunas, multiplicando ainda mais os caminhos de leitura. A única constante é a coluna vertebral formada a partir da aliteração da letra $<0>$, que remete ao poema um movimento e ao arco tenso da poesia concreta. Caviar, contudo, possui um tom satírico, como se discute mais adiante.

\section{caviar o prazer \\ prazer o porvir \\ porvir o torpor \\ contemporalizar}

Figura 3. Poema caviar (1959), de Décio Pignatari. ${ }^{15}$

As pesquisas de Adriana Carolina Hipólito de Assis (2014) e Claudicélio Rodrigues da Silva (2018) já antecipam a discussão sobre os aspectos eróticos do poema caviar. Para Assis (2014, p. 180-181), o poema é o "o corpo desejante para o nosso tempo" conforme acende o "prazer degustativo" com a palavra "caviar", projetando o sentimento do desejo erótico, no qual o caviar é o "alimento poético, a substância afrodisíaca". Assim como Assis, Silva também observa uma presentificação do poema na palavra "contemporalizar", que ecoa a palavra "torpor". Porém, Silva dá um passo adiante na sua análise e identifica nesse eco uma partícula irônica:

A palavra "caviar" que abre o primeiro verso, na condição de verbo, sugere uma continuidade, um movimento que só é cessado concretamente quando

15 Teoria da poesia concreta, 2006, p. 178. 

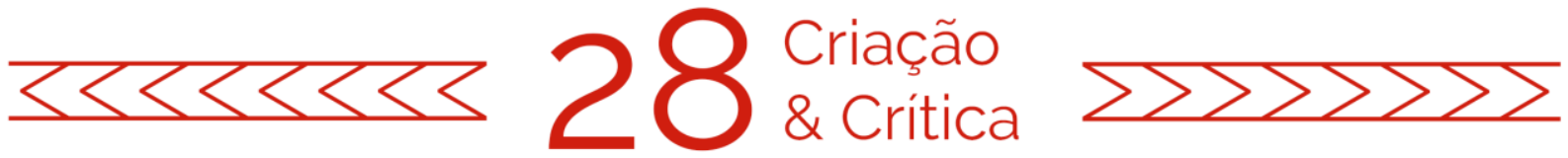

a palavra "torpor" do terceiro verso não aparece como verbo no verso seguinte, mas a palavra "contemporalizar". Assim, o sentido da palavra "torpor" - diminuir ou romper com um movimento, provocar um mal-estar, uma insensibilidade - ocorre diante de nossa leitura, como uma quebra ou interrupção de gozo. A ironia com que o poema se constrói indicam que o prazer e a melancolia andam lado a lado [...]. (SILVA, 2018, p. 21)

Ainda é interessante acrescentar algumas considerações fonéticas relevantes para o desenvolvimento dos jogos eróticos no poema, pois elas também auxiliam a distinguir os tons satíricos e críticos no texto. No início do poema, a palavra "caviar" é o sabor do texto e o prazer luxuoso. Sabor, porque a primeira linha do poema opera a recuperação do gosto do caviar nas papilas gustativas, mesmo naqueles que nunca comeram a iguaria. Luxuoso, pela restrição elitista do alimento.

Em caviar, a aliteração de $<r>$, presente em todas as linhas do poema, torna 0 ruído vibrante uma constante em todo o poema, promovendo um efeito de tremor que ganha força com a fricação dos sons [v] e [z]. O frêmito é costurado junto à assonância da plosiva bilabial vozeada [p], oriunda da aliteração da letra $\langle p\rangle$. Vibração e pulsar são sonoridades que remetem ao erotismo, sussurros e gemidos que permeiam a relação sexual. Porém, como bem observa Silva (2018), o gozo é interrompido, o pulsar do som [p] perde o vozeado no som plosivo velar desvozeado [k], em "contemporalizar", que recoloca o poema no horizonte do presente. Encerra-se o prazer, pois a crítica chama a atenção para o contemporâneo.

Ao relacionar o prazer sexual com um artigo de luxo, Pignatari fez um recorte social, refere-se à elite, à alta sociedade que, por ter poder aquisitivo, come por prazer não por fome - o que há de mais luxuoso, pois busca status social. Rememora-se aqui o poema Ode ao burguês de Mario de Andrade, publicado no livro Paulicéia desvairada ([1922] 2016):



(ANDRADE, 2016, p. 29)

Caviar é repensado à luz do poema de Mario de Andrade. O "burguês-nádegas" é o burguês-caviar, o burguês da década de 1950 em São Paulo é ainda o mesmo "purée de batatas morais" do burguês da década de 1920, apenas mais rico, pois passa das batatas ao caviar. Na "gelatina pasma" da alta sociedade, alguém exerce "as funções de medula e osso" (PIGNATARI, 2006, p. 235), em caviar, a coluna vertebral é estruturada 

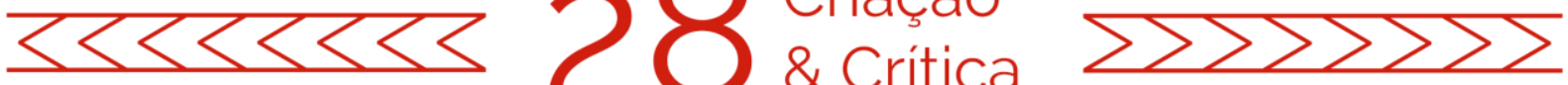

pela repetição da letra $\langle 0\rangle$, que divide o texto ao meio, assim, visualmente identifica-se o "burguês-nádegas" de Mario de Andrade ou as nádegas do burguês-caviar. O tom é satírico, a coluna de letras $<0>$, remete ao órgão que expele o excremento que resulta da digestão do caviar, ela mantém tenso o arco crítico da poesia concreta, é o olho que, apesar de subjugado cego, está aberto e observa toda a podridão dos prazeres da elite.

É importante frisar que essa interpretação não ofende o texto de Pignatari, que, como observa Aguilar (2005, p. 170), era o poeta mais audacioso e menos cerimonioso do trio Noigandres, dotado de "um humor estranho e irreverente". Além disso, outro fato, que ocorre anos mais tarde, auxilia também a validar a leitura satírica, é a capa do disco Todos os olhos (1973) de Tom Zé, elaborada por Pignatari e sobre a qual o poeta conta:

Nós vivíamos no tempo da ditadura militar, da censura e essas coisas. $O$ Tom Zé fez um disco chamado Todos os olhos (1973), e ele pediu para eu fazer um projeto de capa para o disco dele. Ai eu falei, "bom, não vou perguntar, mas será que isso inclui o olho do cu?", então foi aí que eu resolvi, usar esse olho e eu queria fotografar, entende... o olho. [...] E a capa foi feita, e todo mundo estranhava aquilo, é o tempo da ditadura e nós vamos tirar um sarro, fazer uma coisa pornográfica e engraçada, onde as pessoas que descobrirem tudo bem, os que não descobrirem, fica por isso mesmo, fica registrado o nosso protesto contra a ditadura. (PIGNATARI, 2009, n.p. $)^{16}$

A crítica fica também registrada na forma do poema caviar, no qual a letra $<0>$ ou o olho tira sarro do luxo burguês, ironiza aquilo que é indigesto na sociedade. Esse elemento visual satírico se perde na performance oral que Pignatari $(2002)^{17}$ realiza do poema, que, por sua vez, favorece outros elementos sonoros.

A oralização de Pignatari alonga a pronúncia das duas últimas letras das palavras da primeira coluna do poema, isto é, alonga as tônicas [ar], [er] e [ir], de modo que na performance oral a coluna vertebral do poema se move, agora é construída pela assonância de [r:]. A fricação provoca nos ouvidos a sensação de movimento, que se efetiva na boca conforme a declamação das tônicas se desdobra. Resumidamente, a performance de caviar (2002) começa alongando a tônica da vogal anterior aberta [a], a segunda tônica alongada é a vogal anterior meia-fechada [e] e a terceira tônica é a vogal anterior fechada [i], assim, acontece um fechamento gradual dentro da cavidade oral, entre o dorso da língua e o céu da boca. O estreitamento da distância entre os órgãos orais e o alongamento da vibrante [r], remetem ao erotismo do corpo e das sensações sexuais. Na oralização do poema caviar é a língua que se destaca como órgão sensitivo: o gosto e a textura do caviar, o toque entre os corpos e a vibração do prazer.

A última linha termina com a tônica composta pela vogal anterior aberta [a] em "contemporalizar", de modo que o poema começa aberto, se fecha e volta a se abrir,

\footnotetext{
16 Transcrição da entrevista concedida ao programa Caminhos da escola (2009), disponível em <https://www.youtube.com/watch?v=z0a504397D4>, acesso em 14 de junho de 2020.

17 Disponível em: <https://poesiaconcreta.com.br/player.php?acao=play\&id=180\&numero=34>. Acesso em 20 mai. 2020.
} 



pulsando dentro da boca daquele que fala, pulsando dentro do corpo daquele que escuta. Arco tenso e movimento são orquestrados de maneiras distintas no suporte escrito e no áudio, mas estão presentes em ambos. Os jogos mentais depreendidos dos diferentes suportes são as provocações do poeta, que cutuca os tabus com vara curta. É nessa audácia e irreverência que uma parcela da cultura digital busca sabor, na sátira sutil, que não perde de vista o horizonte crítico e presente. Para além da estética, é o desafio e a provocação da fase ortodoxa que estão presentes na literatura digital que a tem a poesia concreta como precursora, o arco continua tenso no contemporâneo, o olho está aberto.

A experimentação que os poemas um movimento (1956), hombre hambre hambra (1957) e caviar (1959) realizam no suporte do áudio os transformam em exemplos bemsucedidos de poemas intermídias. A análise tecida no trabalho ilustrou como o multiálogo intermídia contribui na construção dos símbolos e significados dos objetos artísticos, além de distinguir algumas experiências sensoriais oferecidas aos leitores. O que importa nessa leitura são os jogos mentais que o leitor constrói ativamente, as interpretações que esse produz quando coloca os diferentes suportes em contato. Nesse sentido, o presente trabalho não apenas aquiesce os apontamentos de Santaella (2006) sobre a poesia concreta ser precursora da poesia digital, como também demonstra as proposições da pesquisadora por meio de uma análise dos poemas de Pignatari. A poesia concreta provoca o leitor com as múltiplas possibilidades de leitura, os diferentes efeitos do suporte de inscrição, a ousadia da sátira ácida e polida, o olhar crítico preciso e presente; são também esses aspectos concretos ortodoxos usados pela geração que começa a produzir poesia no ambiente digital.

\section{Referências}

AGUILAR, Gonzalo. Poesia Concreta Brasileira: As vanguardas na encruzilhada modernista. São Paulo: Editora da Universidade de São Paulo, 2005.

ALBERTS, Bruce et al. Biologia molecular da célula. Porto Alegre: Artmed, 2017.

ANDRADE, Mário de. "Ode ao burguês". In: ANDRADE, Mário de. Paulicéia desvairada. Barueri: Ciranda Cultural, 2016.

ASSIS, Adriana Carolina Hipólito. "Imagens de um corpo poe(ró)tico digitalizado". Anuário de literatura: Publicação do Curso de Pós-Graduação em Letras, Literatura Brasileira e Teoria Literária, v. 19, n. 2, p. 169-187, 2014.

CAMPOS, Augusto de. PIGNATARI, Décio CAMPOS, Haroldo de. Teoria da poesia concreta. São Paulo: Ateliê Editorial, ed. 4, 2006.

CAMPOS, Haroldo de. "Olho por olho a olho nu". In: CAMPOS, Augusto de. PIGNATARI, Décio CAMPOS, Haroldo de. Teoria da poesia concreta. São Paulo: Ateliê Editorial, ed. 4, 2006. 

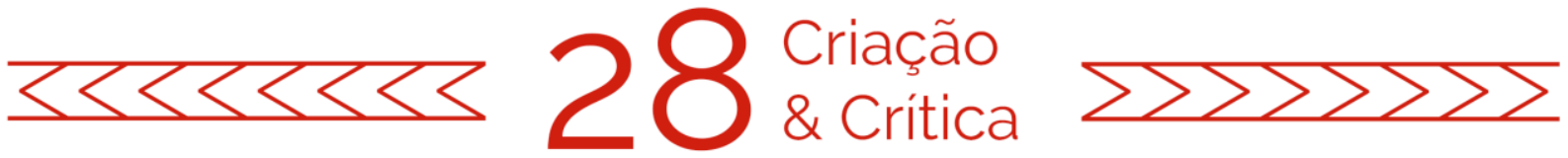

CAMPOS, Haroldo de. "Ruptura dos gêneros na literatura latino-americana". In: MORENO, César Fernández (Org.). América Latina em sua Literatura. São Paulo: Perspectiva, 1979.

CHARTIER, Roger. "Escutar os mortos com os olhos". Estudos Avançados, v. 24, n. 69, p. 7-30, 2010.

CLÜVER, Claus. "Inter textus/ Inter artes/ Inter media". Aletria: revista de estudos de literatura, v. 14, n. 2, p. 10-41, 2006.

CLÜVER, Claus. "Concrete Poetry and the New Performance Arts: Intersemiotic, Intermedia, Intercultural”. In: CLÜVER, Claus. East of West. New York: Palgrave Macmillan, 2000.

EL HAOULI, Janete; MANNIS, José Augusto. "Sound piece: in memoriam Décio Pignatari". Massenmedien und Kommunikation. - Montage Collage Komposition, v. 195/196, p. 135-140, 2014.

MAIAKOVSKI, Vladimir. "A flauta-vértebra”. In: MAIAKOVSKI, Vladimir. Maiakovski. São Paulo: Editora Perspectiva, ed. 3, 1985.

MAINGUENEAU, Dominique. "Oral, escrito, impresso". In: MAINGUENEAU, Dominique. $O$ contexto da obra literária. São Paulo: Martins Fontes, ed. 2, 2001.

MAINHARD, Veruschka Bluhm. Considerações sobre timbre vocal e sua função na obra Noigandres 4 de José Augusto Mannis. In: CONGRESSO DA ANPPOM, ed. 23, 2013. Anais da ANPPOM. Natal, 2013. p. 1-10.

PIGNATARI, Décio. "\& se não perceberam". In: CAMPOS, Augusto de. PIGNATARI, Décio CAMPOS, Haroldo de. Teoria da poesia concreta. São Paulo: Ateliê Editorial, ed. 4, 2006.

PIGNATARI, Décio. "Poesia concreta: organização". In: CAMPOS, Augusto de. PIGNATARI, Décio CAMPOS, Haroldo de. Teoria da poesia concreta. São Paulo: Ateliê Editorial, ed. 4, 2006.

PIGNATARI, Décio. "Entrevista Roda Viva". TV Cultura, 1989. Disponível em: <https://www.youtube. com/watch?v=AUnjYoDDwbM>. Acesso em: 17 mar. 2020.

PIGNATARI, Décio. "Caminhos da escola: episódio 34". TV Escola/ Grupo Conspiração / TV Cultura, 2009. Disponível em: <https://www.youtube.com/watch?v=z0a504397D4>. Acesso em: 14 jun. 2020.

POESIACONCRETA. "um movimento". 1971. Disponível em: $<$ https://poesiaconcreta.com.br/player.php?acao=play\&id=285\&numero=1>. Acesso em: 20 mai. 2020.

POESIACONCRETA. "caviar". $2002 . \quad$ Disponível em: $<$ https://poesiaconcreta.com.br/player.php?acao=play\&id=180\&numero=34>. Acesso em 20 mai. 2020.

POESIACONCRETA. "hombre hambre hambra". 2002. Disponível em $<$ https://poesiaconcreta.com.br/player.php?acao=play\&id=178\&numero=32>. Acesso em 20 mai. 2020. 

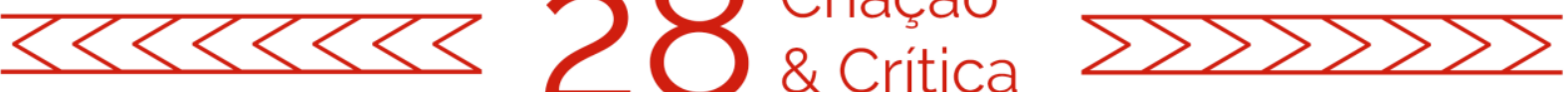

POESIACONCRETA. "um movimento". 2002. Disponível em: $<$ https://poesiaconcreta.com.br/player.php?acao=play\&id=175\&numero=29>. Acesso em: 20 mai. 2020.

POESIACONCRETA. "hombre hambre hambra". 2007. Disponível em: $<$ https://poesiaconcreta.com.br/player. php?acao=play\&id=292\&numero=8>. Acesso em: 20 mai. 2020.

SANTAELLA, Lucia. "A poesia concreta como precursora da cibercultura". Suplemento MG, ed. especial, p. 31-35, 2006.

SANTAELLA, Lucia. "Décio Pignatari entre a vida, os signos e a memória". Interin, v. 21, n. 2, p. 203-217, 2016.

SILVA, Claudicélio Rodrigues da. "O risco de eros na pele do texto: a poesia eróticoconcreta de Décio Pignatari”. Revista Alěre, v. 17, n. 1, p. 15-36, 2018.

Recebido em: 26/06/2020

Aceito em: 27/10/2020

Referência eletrônica: BOMFIM, Monalisa Medrado. Multiálogo e arco tenso: poemas intermídia de Décio Pignatari. Criação \& Crítica, n. 28, p., dez. 2020. Disponível em: $<$ http://revistas.usp.br/criacaoecritica>. Acesso em: dd mmm. aaaa. 